\title{
Selective Capture of Thallium and Cesium by a Cryptophane Soluble at Neutral pH
}

Thierry Brotin, ${ }^{*}+$ Patrick Berthault, ${ }^{\dagger}$ Delphine Pitrat, ${ }^{\dagger}$ Jean-Christophe Mulatier ${ }^{\dagger}$

† University Claude Bernard Lyon 1, ENS de Lyon, CNRS UMR 5182, Laboratoire de Chimie, 69342, Lyon, France

$\$$ University Paris Saclay, CEA, CNRS, Nanoscience and Innovation for Materials, Biomedicine and Energy, 91191 Gif-sur-Yvette, France.

TOC/Graphical Abstract:

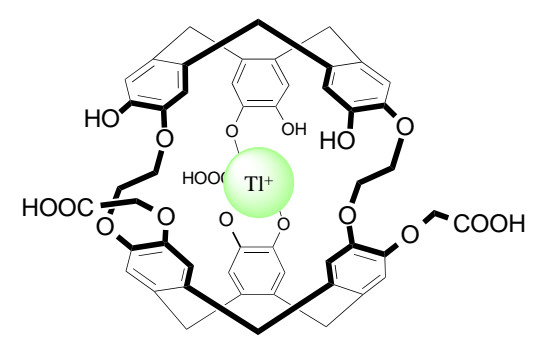

ABSTRACT: We report in this article the synthesis of an asymmetrical cryptophane derivative (possessing only $\mathrm{C}_{3}$-symmetry) bearing three phenol groups and three other carboxylic acid functions, each of these groups on the aromatic rings. Thanks to isothermal titration calorimetry experiments, we show that this compound binds large monovalent cations, such as $\mathrm{Cs}^{+}$and $\mathrm{Tl}^{+}$with a binding constant significantly lower than its congeners bearing a larger number of phenol groups grafted on the benzene rings. However, higher selectivity for $\mathrm{Cs}^{+}$and $\mathrm{Tl}^{+}$was observed with this compound since it does not show any affinity for other alkali cations. More importantly, due to the greater solubility of this derivative in pure water, we show for the first time that effective thallium(I) complexation 
takes place at neutral $\mathrm{pH}$. This result demonstrates that cryptophane derivatives decorated with a higher number of phenol groups are promising host molecules for removing traces of thallium(I) from aqueous phases at neutral $\mathrm{pH}$ or above.

\section{INTRODUCTION}

Thallium is a heavy metal present in low concentration in the earth's crust and it can be found in a large variety of sulphur-containing minerals. ${ }^{1-3}$ In this form this element does not constitute a particular threat for humans and eco-systems in general. However, when released into the environment (mainly as $\mathrm{Tl}(\mathrm{I})$ ) as a result of human activities, this element poses a major threat to humans and all ecosystems. Indeed, this element is considered to be very toxic to human health, even at low concentrations. ${ }^{4-6}$ Its effects on humans and rodents are well documented: an acute exposure is usually fatal and a moderate thallium exposure can induce severe disorders. ${ }^{7,8}$ Surprisingly, despite its high toxicity, this element has not received much attention compared to other heavy metals such as lead, mercury and cadmium.

Concentration of thallium in air, groundwater and soils has considerably increased during the $20^{\text {th }}$ century as a consequence of the human activities. Thallium pollution originates mainly from various types of human activities such as coal combustion, mineral extraction and cement industry. ${ }^{9-13}$ All these activities have contributed to the dispersion of thallium in ecosystems, leading to air, groundwater and soil pollution. In addition, thallium has also been widely used as a rodenticide, which has also contributed to the release of thallium into the wild. ${ }^{14-16}$ Countries such as the United States of America or China that rely heavily on coal industries as a source of energy are directly affected by thallium pollution, but many others are facing thallium pollution from mining activities, for example. ${ }^{17-22}$ 
Different solutions have been proposed to extract Tl(I) from soil and groundwater. ${ }^{23-29}$ Among them, macrocyclic compounds with a good affinity for $\mathrm{Tl}(\mathrm{I})$ are assumed to be promising host derivatives for removing traces of $\mathrm{Tl}(\mathrm{I})$ in soil water. ${ }^{30}$ For instance, Calix $[\mathrm{n}]$ arene $(\mathrm{n}=4-6)$ and crown-ether derivatives show good affinity and selectivity for Tl(I). These molecules have been incorporated into various systems to detect traces of thallium in water, even in the presence of other cationic species. ${ }^{31-35}$

More recently, another class of macrocyclic derivatives showing high affinity for $\mathrm{Tl}(\mathrm{I})$ in aqueous solution has emerged. ${ }^{36-38}$ These compounds are interesting because the number of host molecules that can bind $\mathrm{Tl}(\mathrm{I})$ in aqueous phase are rather limited and most of the studies reported in the literature have concerned macrocyclic compounds dissolved in organic solvents. ${ }^{39-44}$ These derivatives also show good affinity for $\mathrm{Cs}^{+}$cations, but association constants have been shown to be generally an order of magnitude lower under the same experimental conditions. Anyway, studying comparatively the interaction of large cations such as $\mathrm{Tl}^{+}$and $\mathrm{Cs}^{+}$with these host molecules represents good challenge. This class of compounds can be defined as hollow-type macrocyclic compounds and they have been named cryptophane derivatives for simplicity. ${ }^{45}$ These derivatives are made of two cyclotribenzylene (CTB) caps connected together by three alkoxy linkers whose length and nature can be varied. Interestingly, they can also be decorated with different substituents, depending on the application wanted. In recent articles, we have shown that the presence of phenol groups grafted onto the benzene rings (Chart 1: compound 1) allows these molecules to bind $\mathrm{Cs}^{+}$and $\mathrm{Tl}^{+}$in aqueous solution with a very high efficacy. These host molecules are also able to recognize other alkali cations such as $\mathrm{Rb}^{+}$and $\mathrm{K}^{+}$but the association constants measured under the same conditions are several orders of magnitude lower than those observed for $\mathrm{Tl}^{+}$ and $\mathrm{Cs}^{+}$. We concluded that the presence of phenol groups is mandatory to observe an efficient complexation of $\mathrm{Tl}^{+}$and $\mathrm{Cs}^{+}$and the introduction of other functionalities on the 
cryptophane skeleton leads to a lack of recognition. For instance, the replacement of all phenol functions by carboxylic acid groups led to a compound that do not show any affinity for $\mathrm{Cs}^{+}$and $\mathrm{Tl}^{+}$cations (Chart 1: compound 2).

The recognition process can be easily detected by several techniques such as isothermal titration experiments (ITC), ${ }^{205} \mathrm{Tl}$ NMR spectroscopy and ${ }^{133} \mathrm{Cs}$ NMR spectroscopy. To date, basic conditions were necessary to perform these experiments with cryptophane derivatives since these host molecules are strongly lipophilic and are consequently not soluble at neutral $\mathrm{pH}$. Thus, the ability of new cryptophane derivatives to bind thallium and cesium cations at neutral $\mathrm{pH}$ remains to be determined. The demonstration of the ability of these molecules to bind the cesium and especially $\mathrm{Tl}(\mathrm{I})$ cations at neutral $\mathrm{pH}$ would be extremely interesting for future applications in environmental chemistry.

Recently, we have reported a synthetic procedure that allowed us to prepare in a single step new asymmetrical anti-cryptophane and syn-cryptophane derivatives with $\mathrm{C}_{3}$ symmetry. ${ }^{46}$ Interestingly, these new derivatives possess reactive chemical functions that can be easily functionalized at latter stages to build-up new derivatives that could not otherwise be synthesized. Thus, from these compounds, it is possible to prepare cryptophane derivatives having different functionalities on each CTB units, such as compound $\mathbf{3}$, which has three phenol functions grafted on one CTB unit and three carboxylic acid functions grafted onto the other CTB unit (Chart 1: compound 3). From a structure point of view this compound can be seen as intermediate between compounds $\mathbf{1}$ and $\mathbf{2}$. Thus, the similarity of compound $\mathbf{3}$ with these two structures and their different affinity with respect to the cesium and the thallium cations prompted us to investigate the binding properties of compound $\mathbf{3}$ with these two species in more details.

We report in this paper the synthesis of compound $\mathbf{3}$ and we study its ability to bind thallium, cesium and other alkali cations in aqueous solution. Isothermal Titration 
Calorimetric experiments (ITC), ${ }^{205} \mathrm{Tl}$ and ${ }^{133} \mathrm{Cs}$ NMR spectroscopy have been used to study the binding process with these two cations. Due to the non-negligible solubility of compound 3 in pure water, it is possible for the first time to assess the thallium and cesium binding properties of a phenol-containing cryptophane at neutral $\mathrm{pH}$.

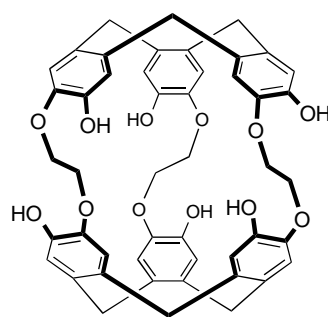

1

high affinity for $\mathrm{Tl}^{+}$

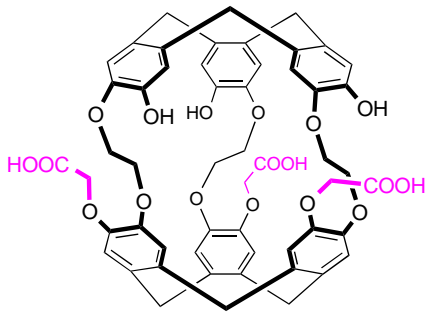

3

$?$

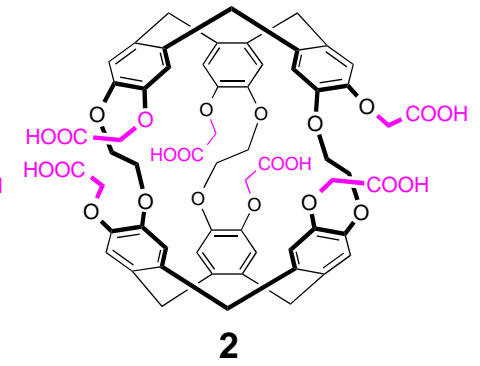

no affinity for $\mathrm{Tl}^{+}$

CHART 1: Chemical structures of compounds 1-3 (a single enantiomer is show).

\section{RESULTS}

Synthesis of compound 3: A cryptophane (compound 4; $\mathrm{C}_{3}$-symmetry) of anti configuration bearing three phenol moieties and three benzyl groups has recently been reported in the literature. ${ }^{46}$ This new derivative offers many advantages as it allows different functionalities to be grafted onto the two CTB caps, thus extending the chemistry of these derivatives. For instance, this compound was used as a starting material to prepare the water-soluble cryptophane $\mathbf{3}$. It is noteworthy that compound $\mathbf{3}$ has recently been used as a $\mathrm{pH}$ sensor in combination with laser-polarized xenon NMR. ${ }^{47}$

Two different strategies were tested to prepare cryptophane 3: the synthetic pathway 1, named the two-step approach, requires the use of two different protecting groups to protect both the phenol and the ester functions. In contrast, the synthetic pathway 2, named the one-step approach, uses the same protecting groups for both chemical functions. In the two-step approach, compound $\mathbf{4}$ was allowed to react with an excess of methylbromoacetate (5) to give 
rise to compound $\mathbf{6}$ in $90 \%$ yield. Thus, compound $\mathbf{6}$ possesses two orthogonal protective groups (three methyl and three benzyl groups) that can be easily removed at different stages of the synthesis. In contrast, in the one step-approach, methylbromoacetate (5) is replaced by its benzylbromoacetate analogue (7). Using the same methodology reported for $\mathbf{6}$, compound 8 was prepared in $80 \%$ yield by reacting compound 4 with an excess of 7 . The introduction of six benzyl groups in compound $\mathbf{8}$ may be an advantage in preparing compound $\mathbf{3}$ in a single step, but we found that compound $\mathbf{8}$ was more difficult to isolate due to its higher lipophilicity. Deprotection of the three benzyl ester groups of $\mathbf{7}$ was performed by hydrogenolysis with palladium on charcoal $(\mathrm{Pd} / \mathrm{C} ; 10 \%)$ as a catalyst in a mixture of $\mathrm{CH}_{2} \mathrm{Cl}_{2} / \mathrm{MeOH}$. This gave compound 9 in $97 \%$ yield. Unfortunately, the selective deprotection of the three methyl ester groups (synthetic pathway 1) performed in $\mathrm{KOH} / \mathrm{D}_{2} \mathrm{O}$ in the presence of THF did not allow us to obtain the desired compound. Indeed, although we noticed that deprotection of the three ester functions took place, the ${ }^{1} \mathrm{H}$ NMR spectrum of the crude revealed a very complicated spectrum due to the presence of the imploded form in significant amounts. The presence of the imploded form makes therefore the synthetic pathway 1 useless since this peculiar conformation does not show any interesting binding properties. In addition, the presence of two stable conformations in solution (inflated and imploded) would complicate the interpretation of our results. In contrast, the hydrogenolysis reaction (synthetic pathway 2) performed with compound 8 with $\mathrm{Pd} / \mathrm{C}$ in a $\mathrm{CH}_{2} \mathrm{Cl}_{2} / \mathrm{MeOH}$ mixture allowed us to obtain compound $\mathbf{3}$ with a good yield. In this example, compound $\mathbf{3}$ was recovered without any imploded form as shown by ${ }^{1} \mathrm{H}$ NMR spectroscopy. Compound 3 and 7-9 have been fully characterized by ${ }^{1} \mathrm{H}$ and ${ }^{13} \mathrm{C}$ NMR spectroscopy and HRMS (See Supporting Information S4-S11). Compound 3 was found very soluble in DMSO and in water under basic condition. Importantly, we also observed that this compound is also slightly soluble at neutral $\mathrm{pH}$. 


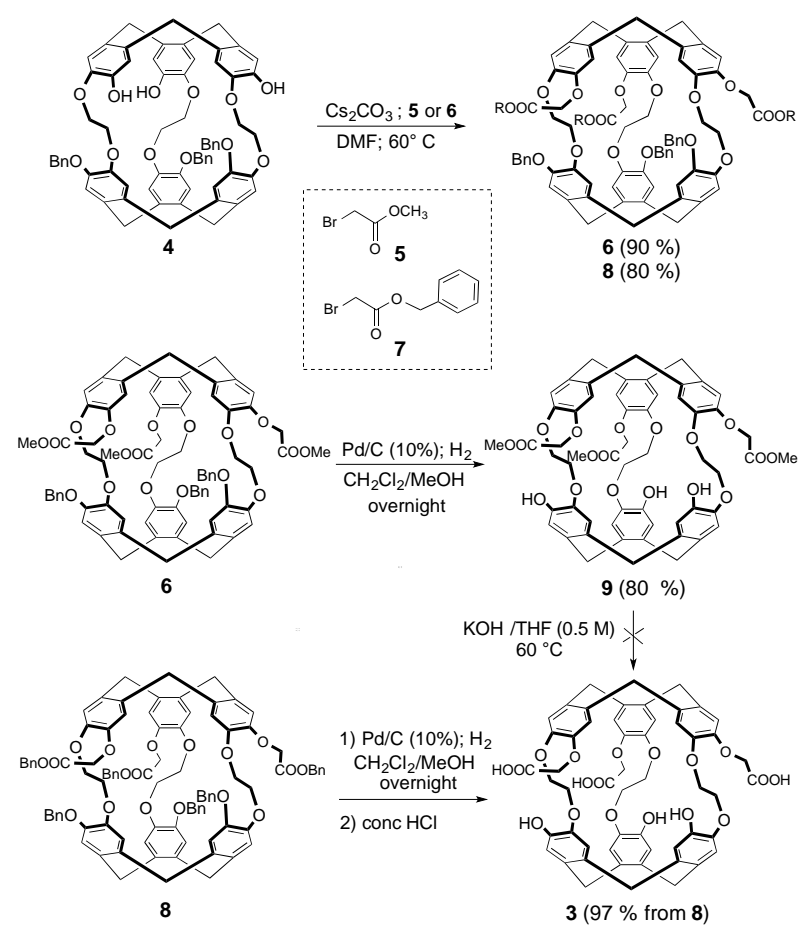

SCHEME 1: synthesis of cryptophane 3 according to two different synthetic routes.

${ }^{133} \mathrm{Cs}$ and ${ }^{205}$ TI NMR spectroscopy: ${ }^{133}$ Cs NMR spectroscopy of compound $\mathbf{3}$ in the presence of $\mathrm{CsOH}$ was recorded at $290 \mathrm{~K}$ in $\mathrm{NaOH}(0.1 \mathrm{M})$. In a previous article, Cryptophane $\mathbf{1}$ and some of its congeners were studied in basic aqueous solution because these molecules have a good solubility under these conditions. Thus, in the present study, compound $\mathbf{3}$ was first studied under the same conditions for comparison purposes. Indeed, the presence of a characteristic signal at a low frequency relative to free $\mathrm{Cs}^{+}$would be a good indication that compound $\mathbf{3}$ can accommodate this cation under the same conditions.

At this temperature, the NMR spectrum shows a single signal located near $0 \mathrm{ppm}$, which is characteristic of $\mathrm{Cs}^{+}$in the bulk. Another very broad signal, upfield shifted, can be detected with difficulties but at this temperature it is difficult to assign it to the $\mathrm{Cs}^{+} @ \mathbf{3}$ complex. However, lowering the temperature to $285 \mathrm{~K}$ confirms this second ${ }^{133} \mathrm{Cs}$ NMR signal $(\delta \sim$ $250 \mathrm{ppm}$ ). This signal is still broad but becomes sharper as the temperature decreases (see 
Figure 1). For instance, at $275 \mathrm{~K}$, which is the lowest temperature that we could reach, the ${ }^{133} \mathrm{Cs}$ NMR spectrum reveals a sharp signal at $-248.0 \mathrm{ppm}$, which is characteristic of the formation of the $\mathrm{Cs}^{+} @ \mathbf{3}$ complex, see Figure 1).
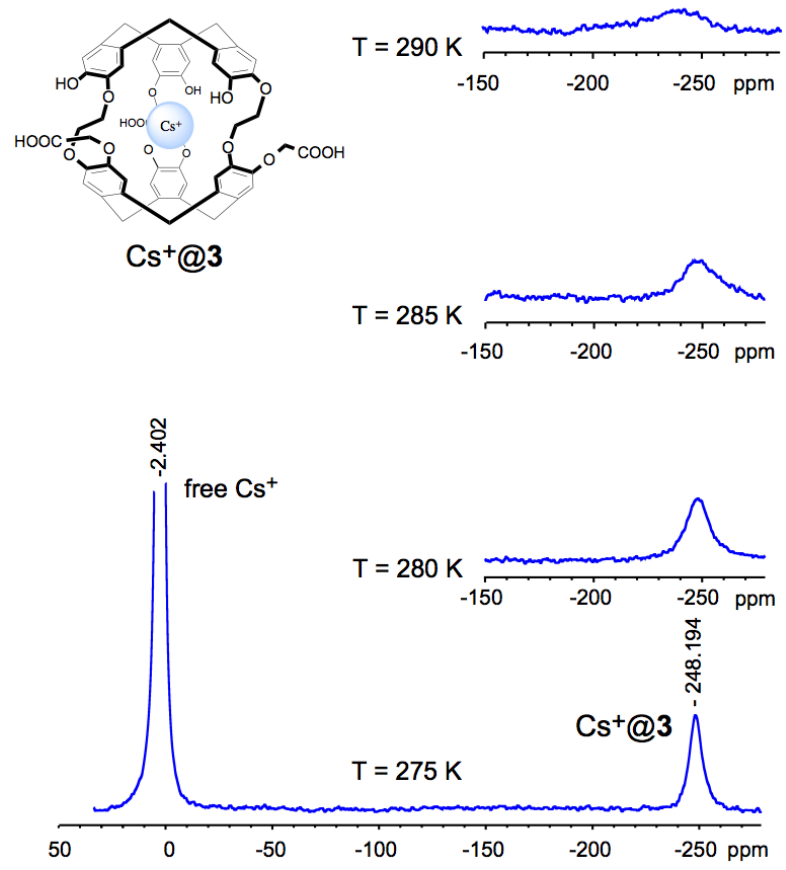

Figure 1: ${ }^{133} \mathrm{Cs}$ NMR spectroscopy of 3 in the presence of $\mathrm{CsOH}$ in $\mathrm{NaOH}(0.1 \mathrm{M})$ recorded at several temperature (290, 285, 280, 275 K). Left signal: free $\mathrm{Cs}^{+}$in the bulk. Right signal: $\mathrm{Cs}^{+} @ 3$ complex.

${ }^{205} \mathrm{Tl}$ NMR spectroscopy was found more difficult to achieve because the ${ }^{205} \mathrm{Tl}$ nucleus resonates at a frequency, which is too high for most of commercial broadband NMR probes, and too low to be detected by the ${ }^{1} \mathrm{H}$ channel. However, detection of this nucleus was made possible by using a homemade system (see experimental section). At room temperature, a sample of cryptophane 3 in $\mathrm{NaOH}$ in the presence of a small amount of thallium acetate revealed only a broad signal at $440 \mathrm{ppm}$. No other ${ }^{205} \mathrm{Tl}$ NMR signal was detected at lower frequency that could indicate the formation of the $\mathrm{Tl}^{+} @ \mathbf{3}$ complex at this temperature (see Supporting Information S12). Unfortunately, our homemade system does not allow us to record ${ }^{205} \mathrm{Tl}$ NMR spectra at even lower temperature. Anyway this result is consistent with 
that obtained with ${ }^{133}$ Cs NMR spectroscopy, which shows no specific spectral signature for the ${ }^{133} \mathrm{Cs} @ 3$ complex at room temperature.

Titration experiments: Isothermal titration calorimetry (ITC) appears to be the method of choice to measure accurately the association constants between compound $\mathbf{3}$ and cationic species in aqueous solution. In addition, all the parameters associated to this binding process can be easily determined or calculated from the enthalpogram. For instance, both the binding constant and the enthalpy of complexation $\Delta \mathrm{H}^{0}$ can be measured from the ITC experiments. In turn, the free enthalpy $\Delta \mathrm{G}^{0}$ and entropy $\Delta \mathrm{S}^{0}$ of complexation can be easily calculated from these data. ITC experiments were carried out under different conditions and the results are summarized in Table 1 and Table 2. Here again, for comparison purposes, compound $\mathbf{3}$ was first investigated under basic conditions. In $\mathrm{LiOH}(0.1 \mathrm{M})$, host 3 binds moderately $\mathrm{Cs}^{+}$with a binding constant $\mathrm{K}=11000 \mathrm{M}^{-1}$ at $298 \mathrm{~K}$ (see Supporting Information S13). A change of the base used to prepare the solution $(\mathrm{NaOH}$ and $\mathrm{KOH})$ leads to a small decrease of the binding constant and binding constants. Binding constants $\mathrm{K}=8700 \mathrm{M}^{-1}$ and $8300 \mathrm{M}^{-1}$ have been obtained at $298 \mathrm{~K}$ in $\mathrm{NaOH}(0.1 \mathrm{M})$ and $\mathrm{KOH}(0.1 \mathrm{M})$, respectively (see Supporting Information S14-S15). Interestingly, higher binding constants have been measured with thallium. For instance, at $298 \mathrm{~K}$ a binding constant $\mathrm{K}=4.2 \times 10^{5} \mathrm{M}^{-1}$ has been measured for this cation in $\mathrm{LiOH}(0.1 \mathrm{M})$ (Figure 2). A change of the nature of the basic solution does not significantly modify the binding constant since $\mathrm{K}=3.93 \times 10^{5} \mathrm{M}^{-1}$ and $3.53 \times 10^{5} \mathrm{M}^{-1}$ have been measured respectively in $\mathrm{NaOH}(0.1 \mathrm{M})$ and $\mathrm{KOH}(0.1 \mathrm{M})$, respectively (See Supporting Information S16-S17).

Interestingly, the moderate solubility of compound $\mathbf{3}$ allows us for the first time to investigate the binding properties of cesium and thallium at neutral $\mathrm{pH}$. In order to avoid any change of the $\mathrm{pH}$ of the solution upon slight addition of the analyte, these experiments have been 
performed in the presence of a HEPES buffer. Thus, an ITC experiment performed in HEPES $(10 \mathrm{mM} ; \mathrm{pH}=7.28)$ with compound 3 in the presence of $\mathrm{Cs}^{+}$gives rise to a moderate binding constant $\mathrm{K}=650 \mathrm{M}^{-1}$ at $298 \mathrm{~K}$ (See Supporting Information S18). Lowering the temperature to $288 \mathrm{~K}$ leads to a slight increase of this constant $\mathrm{K} \sim 1250 \mathrm{M}^{-1}(\mathrm{HEPES}, 10 \mathrm{mM}$; $\mathrm{pH}=7.18$ ) (See Supporting Information S19).

Higher association constants have been measured for the $\mathrm{Tl}^{+} @ 3$ complex. Decreasing the pH of the solution to $\mathrm{pH}=9.2$ (TRIS buffer) gives rise to a decrease of the binding constant $\mathrm{K}=$ $9300 \mathrm{M}^{-1}$ (See Supporting Information S20). At $\mathrm{pH}=7.12$ and $\mathrm{pH}=7.71$ (HEPES buffer, 10 $\mathrm{mM}$ ) the association constants measured are $\mathrm{K}=5800 \mathrm{M}^{-1}$ and $6700 \mathrm{M}^{-1}$, respectively (See Figure 2 and Supporting Information S21).

It is noteworthy that compound $\mathbf{3}$ does not show any affinity for other alkali cations such as $\mathrm{K}^{+}$and $\mathrm{Rb}^{+}$under the same conditions. For instance, an ITC experiment performed in $\mathrm{LiOH}$ $(0.1 \mathrm{M})$ at $298 \mathrm{~K}$ does not reveal any specific interaction between host $\mathbf{3}$ and the $\mathrm{K}^{+}$cation (See Supporting Information S22). A similar result was obtained with the $\mathrm{Rb}^{+}$cation (See Supporting Information S23).
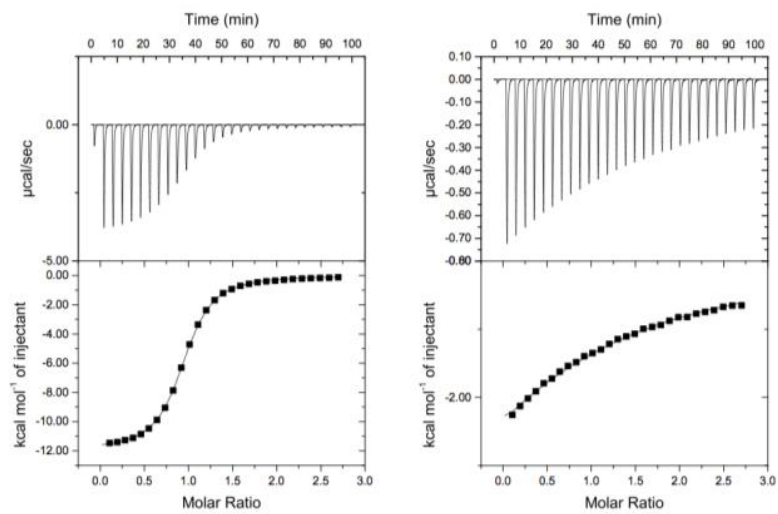

Figure 2: Isothermal Titration Experiments recorded at $298 \mathrm{~K}$ of compound $\mathbf{3}$ in the presence of TlOAc. a) Calorimetric titration of 3 in $\mathrm{LiOH} / \mathrm{H}_{2} \mathrm{O}$ at $298 \mathrm{~K}$. The host solution $(\mathrm{c}=0.08 \mathrm{mM})$ was placed into the calorimeter cell $(1.4 \mathrm{~mL})$ and 28 successive aliquots $(10 \mu \mathrm{L})$ of TlOAc solution $(\mathrm{c}=0.99 \mathrm{mM})$ were added at 3 min intervals. Stoichiometry $\mathrm{n}=1.04$. b) Calorimetric titration of $\mathbf{3}$ in HEPES buffer $(10 \mathrm{mM} ; \mathrm{pH}=7.12)$ at 298 
$\mathrm{K}$. The host solution $(\mathrm{c}=0.08 \mathrm{mM})$ was placed into the calorimeter cell $(1.4 \mathrm{~mL})$ and 28 successive aliquots $(10$ $\mu \mathrm{L})$ of TlOAc solution $(\mathrm{c}=0.99 \mathrm{mM})$ were added at 3 min intervals. The curve fitting process of the ITC data is reported for a Stoichiometry $\mathrm{n}=1.0$.

Table 1: thermodynamic parameters of complexation $\mathrm{K}, \Delta \mathrm{H}^{0}, \mathrm{~T} \Delta \mathrm{H}^{0}$ and $\Delta \mathrm{G}^{0}$ for the $\mathrm{Cs} \mathrm{s}^{+} @ 3$ complex recorded at $298 \mathrm{~K}$ in various solvents. The values reported have been obtained from isothermal titration (ITC) experiments. $a$ : HEPES buffer $(10 \mathrm{mM} ; \mathrm{pH}=7.28)$.

\begin{tabular}{ccccc}
\hline Solvents & $\mathrm{K}\left(\mathrm{M}^{-1}\right)$ & $\Delta \mathrm{H}^{0}(\mathrm{kcal} / \mathrm{mol})$ & $\mathrm{T} \Delta \mathrm{S}^{0}(\mathrm{kcal} / \mathrm{mol})$ & $\Delta \mathrm{G}^{0}(\mathrm{kcal} / \mathrm{mol})$ \\
$\mathrm{LiOH}(0.1 \mathrm{M})$ & 11000 & -8.2 & -2.7 & -5.5 \\
$\mathrm{NaOH}(0.1 \mathrm{M})$ & 8700 & -10.7 & -5.3 & -5.4 \\
$\mathrm{KOH}(0.1 \mathrm{M})$ & 8300 & -9.6 & -4.3 & -5.3 \\
$\mathrm{HEPES}^{a}$ & 640 & -6.2 & -2.4 & -3.9 \\
\hline
\end{tabular}

Table 2: thermodynamic parameters of complexation $\mathrm{K}, \Delta \mathrm{H}^{0}, \mathrm{~T} \Delta \mathrm{H}^{0}$ and $\Delta \mathrm{G}^{0}$ for the $\mathrm{Tl}^{+} @ 3$ complex recorded at $298 \mathrm{~K}$ in various solvents. The values reported have been obtained from isothermal titration (ITC) experiments. $a$ : TRIS buffer $(10 \mathrm{mM} ; \mathrm{pH}=9.2) . b$ : HEPES buffer $(10 \mathrm{mM} ; \mathrm{pH}=7.28)$. c: another experiment performed at $\mathrm{pH}=7.71$ gives rise to a binding constant $\mathrm{K}=6700 \mathrm{M}^{-1}$ (see Supporting Information S21).

\begin{tabular}{ccccc}
\hline Solvents & $\mathrm{K}\left(\mathrm{M}^{-1}\right)$ & $\Delta \mathrm{H}^{0}(\mathrm{kcal} / \mathrm{mol})$ & $\mathrm{T} \Delta \mathrm{S}^{0}(\mathrm{kcal} / \mathrm{mol})$ & $\Delta \mathrm{G}^{0}(\mathrm{kcal} / \mathrm{mol})$ \\
$\mathrm{LiOH}(0.1 \mathrm{M})$ & $4.210^{5}$ & -12.0 & -4.3 & -7.7 \\
$\mathrm{NaOH}(0.1 \mathrm{M})$ & $3.9310^{5}$ & -11.5 & -3.8 & -7.7 \\
$\mathrm{KOH}(0.1 \mathrm{M})$ & $3.5310^{5}$ & -11.5 & -3.9 & -7.6 \\
TRIS buffer $^{a}$ & $9300^{\mathrm{a}}$ & -7.8 & -2.5 & -5.3 \\
HEPES buffer $^{b}$ & $5750^{\mathrm{c}}$ & -7.2 & -2.1 & -5.1 \\
\hline
\end{tabular}

\section{DISCUSSION:}

The recent synthesis of asymmetrical cryptophanes, such as compound $\mathbf{4}$, allows us to design new original cryptophane derivatives bearing different substituents positioned on each CTB unit. Thus, from the partially protected cryptophane $\mathbf{4}$ used as a starting material, we have been able to introduce specifically three protected carboxylic acid moieties on the same CTB unit whereas the second CTB unit can be decorated with other functionalities. It is noteworthy 
that this kind of cryptophane such as compound $\mathbf{3}$ could not be easily prepared with the previous strategies described in the literature. In this article two different synthetic pathways have been proposed to prepare this derivative. The two-step approach is interesting as it offers the opportunity to design different cryptophane derivatives by taking advantage of the presence of the three phenol functions. Unfortunately, as already observed in the past with cryptophane $\mathbf{3}$ congeners, the deprotection step performed under basic conditions may result in the formation of the imploded form in significant amount. This particular conformation can be easily identified by ${ }^{1} \mathrm{H}$ NMR spectroscopy as it gives rise to characteristic ${ }^{1} \mathrm{H}$ NMR signals and it decreases the molecular symmetry of the cryptophane, thus resulting in a very complex spectrum. As the host of interest is made of two different CTB units two different structures can be drawn for the imploded form of $\mathbf{3}$ (see supporting information S21). Of course, this result does not mean that basic conditions cannot be used for deprotection of methyl ester functions. For instance the well-known hexacarboxylate cryptophane is usually prepared in this way and the imploded form is usually absent or present only in a small proportion. ${ }^{48}$ Our results show that the deprotection of ester groups under basic conditions is highly dependent on the structure of the cryptophane under study and that great attention must be paid to the experimental conditions used. This peculiar problem was also encountered recently with cryptophane derivatives having a slightly larger cavity. ${ }^{49}$ In contrast, the one-step approach, that use milder conditions allow us to prepare compound $\mathbf{3}$ without formation of the imploded form. In addition, in this example, the hydrogenolysis of the benzyl moieties takes place in $\mathrm{CH}_{2} \mathrm{Cl}_{2}$, a solvent that can easily adapt to the host cavity and prevents host collapse.

Our results clearly show that compound $\mathbf{3}$ is able to recognize $\mathrm{Cs}^{+}$and $\mathrm{Tl}^{+}$cations in a large range of conditions. For instance, ${ }^{133}$ Cs NMR spectroscopy reveals a specific spectral signature for the $\mathrm{Cs}^{+} @ 3$ complex at lower frequencies $(\delta \sim-249 \mathrm{ppm}$ at $275 \mathrm{~K})$. It can be observed that this system resonates in the same spectral range as the $\mathrm{Cs}^{+} @ \mathbf{1}$ complex and its 
congeners, all of which exhibit a characteristic signature between -250 and $-270 \mathrm{ppm} .{ }^{50}$ This down-shifted NMR signature is the consequence of the strong shielding effect induced by the six aromatic rings surrounding the cesium cation. In contrast to compound $\mathbf{1}$, the ${ }^{133} \mathrm{Cs} \mathrm{NMR}$ signal of the $\mathrm{Cs}^{+} @ 3$ complex is not clearly defined at room temperature but a clear NMR signature is observed at lower temperature for this complex. Temperature has an inverse effect on these two complexes. For instance, an increase of the temperature (up to 340 in basic water) results in a strong sharpening of the ${ }^{133} \mathrm{Cs}$ NMR signal of the $\mathrm{Cs}^{+} @ 1$ complex. Other water-soluble cryptophanes having very high affinity for $\mathrm{Cs}^{+}$show a similar behaviour. In contrast a sharpening of the ${ }^{133} \mathrm{Cs}$ NMR signal effect with temperature lowering has been observed with cryptophane derivatives showing lower affinity for $\mathrm{Cs}^{+}$, as observed with the $\mathrm{Cs}^{+} @ 3$ complex. ${ }^{37}$ This result is supported by the isothermal titration calorimetry experiments that show a significant decrease of the association constant with respect to compound $\mathbf{1}$. For instance in $\mathrm{LiOH}(0.1 \mathrm{M})$ at $298 \mathrm{~K}$ an association constant $\mathrm{K}=2.7 \times 10^{9} \mathrm{M}^{-1}$ has been reported for the $\mathrm{Cs}^{+} @ \mathbf{1}$ complex. In the same conditions the $\mathrm{Cs}^{+} @ \mathbf{3}$ complex shows an association constant lowered by several orders of magnitude, $K=11000 \mathrm{M}^{-1}$. This leads to a free enthalpy of complexation $\Delta \mathrm{G}^{0}=-5.5 \mathrm{kcal} \mathrm{mol}^{-1}$ at $298 \mathrm{~K}$. As this was suggested previously after study of different $\mathrm{Cs}^{+} @$ cryptophane derivatives, the number of phenol groups grafted onto the cryptophane skeleton has a strong effect on the recognition of alkali cations by cryptophanes. For instance, DFT calculation has revealed that coulombic interactions between cesium and the phenolate moiety play a key role in the stabilisation of the cryptophane complexes. ${ }^{38}$ Thus the removal of three phenol groups has a tremendous effect of the ability of $\mathbf{3}$ to bind alkali cations. For instance, we observed, in contrast to compound $\mathbf{1}$, that this compound is unable to accommodate $\mathrm{Rb}^{+}$in the same condition whereas compound $\mathbf{1}$ still shows a good affinity for this cation with an association constant $\mathrm{K}=9.2 \times 10^{5} \mathrm{M}^{-1}$ in $\mathrm{LiOH}(0.1 \mathrm{M})$. In $\mathrm{NaOH}(0.1 \mathrm{M})$ and $\mathrm{KOH}(0.1 \mathrm{M})$ slightly lower association constants have been measured in these two 
solvents leading to free enthalpy of complexation values $\Delta \mathrm{G}^{0}=-5.5$ and $\Delta \mathrm{G}^{0}=-5.4 \mathrm{kcal} \mathrm{mol}{ }^{-}$ 1, respectively (see Table 1 and Supporting Information S22). In these two solvents, an increase of the enthalpy of complexation is compensated by an increase of the negative entropic term $\Delta \mathrm{S}^{0}$.

Thanks to the introduction of three carboxylic moieties grafted onto the cryptophane skeleton compound $\mathbf{3}$ possesses a sufficient solubility in water to perform ITC experiments at neutral pH. Thus, in HEPES buffer $(\mathrm{pH}=7.28)$, compound 3 shows a low affinity $\left(\mathrm{K}=600-700 \mathrm{M}^{-}\right.$ ${ }^{1}$ ) for $\mathrm{Cs}^{+}$at $298 \mathrm{~K}$. This result has interesting consequences because it suggests that cryptophane $\mathbf{1}$ and its congeners having six phenol moieties can bind more efficiently $\mathrm{Cs}^{+}$at neutral $\mathrm{pH}$. However, the solubility of these host molecules in water is not sufficient to measure the association constants by ITC experiments. Nevertheless, their integration into a polymer matrix or nanoparticles can easily be designed to promote their solubility in water. Note that the structure of these cryptophanes has recently been modified in order to facilitate the grafting of these molecules onto polymers or other solid matrices for instance. ${ }^{51}$

As observed with all cryptophane derivatives bearing phenol groups, compound $\mathbf{3}$ exhibits a larger affinity for $\mathrm{Tl}^{+}$than for $\mathrm{Cs}^{+}$in the same experimental conditions. This affinity is at least an order of magnitude higher than the one observed for $\mathrm{Cs}^{+}$. Compared to cesium, the better affinity of thallium for water-soluble cryptophanes has been verified with different systems. DFT calculations have clearly established that thallium interacts more strongly with the CTB units of cryptophanes than cesium. ${ }^{38}$ Here again, in $\mathrm{LiOH}(0.1 \mathrm{M})$ at $298 \mathrm{~K}$, the association constant $\mathrm{K}=4.2 \times 10^{5} \mathrm{M}^{-1}$ between host 3 and thallium is significantly larger than the one measured with cesium. This leads to a measured free enthalpy of complexation $\Delta \mathrm{G}^{0}=-7.7 \mathrm{kcal} \mathrm{mol}^{-1}$ (Table 2 and Supporting Information S22). As observed with the $\mathrm{Cs}^{+} @ 3$ complex the large enthalpy of complexation $\Delta \mathrm{H}^{0}=-12.0 \mathrm{kcal} \mathrm{mol}^{-1}$ is compensated by a large negative entropic term $\mathrm{T} \Delta \mathrm{S}^{0}=-4.3 \mathrm{kcal} \mathrm{mol}^{-1}$. Interestingly, these 
values are not affected by a change of the experimental conditions since similar $\mathrm{K}, \Delta \mathrm{H}^{0}$ and $\mathrm{T} \Delta \mathrm{S}^{0}$ values are obtained in $\mathrm{NaOH}$ and $\mathrm{KOH}$ solutions. Indeed, contrary to what is observed with host $\mathbf{1}$, the $\mathrm{K}^{+}$cation does not show any affinity for host $\mathbf{3}$. Thus, compound $\mathbf{3}$ has lower affinity for both thallium and cesium but it presents a better selectivity since other alkali cations such as $\mathrm{K}^{+}$or $\mathrm{Rb}^{+}$are not recognized by this host.

Lowering the $\mathrm{pH}$ of the solution $(\mathrm{pH}=9.2$; TRIS buffer) results in a decrease of the association constant $\mathrm{K} \sim 8000 \mathrm{M}^{-1}\left(\Delta \mathrm{G}^{0}=-5.3 \mathrm{kcal} \mathrm{mol}^{-1}\right.$ at $\left.298 \mathrm{~K}\right)$. At this $\mathrm{pH}$ value, which is of the same order of magnitude as the $\mathrm{pK}$ value of a phenolic function, the proportion of phenolate function decreases significantly, resulting in both a reduction of the coulombic interaction with thallium and of the electron density of the benzene rings. At lower $\mathrm{pH}$ value (HEPES buffer, $\mathrm{pH}=7.12$ ) the same trend is observed and an association constant $\mathrm{K} \sim 6000$ $\mathrm{M}^{-1}$ between $\mathrm{Tl}^{+}$and host $\mathbf{3}$ has been measured, suggesting that recognition of thallium is still effective at a neutral $\mathrm{pH}$. It should be mentioned that an increase in the number of phenol groups on a cryptophane skeleton would result in higher association constants for thallium recognition at neutral $\mathrm{pH}$. Thus, the integration of these derivatives into solid matrix (polymer, nanoparticles) would certainly be very useful to build-up new materials for the extraction of traces of thallium of aqueous phases contaminated with thallium.

\section{CONCLUSION}

In this article we report the synthesis of a water-soluble cryptophane bearing two different functionalities onto the benzene rings: three phenol and three carboxylic acid moieties. We show that only $\mathrm{Cs}^{+}$and $\mathrm{Tl}^{+}$cations are well recognized by this new host over a large $\mathrm{pH}$ range. Compared to the other cryptophane studied so far, compound $\mathbf{3}$ shows a better 
selectivity since other alkali cations do not show any affinity for this host. The association constants measured with compound $\mathbf{3}$ are somewhat lower than the association constants observed with compound 1 that possesses six phenol functions. For the first time we have assessed the ability of a water-soluble cryptophane derivative to bind $\mathrm{Tl}^{+}$at neutral $\mathrm{pH}$, thanks to the higher solubility of compound $\mathbf{3}$ in these conditions. Thus, we have demonstrated that this compound shows a moderate affinity for $\mathrm{Tl}^{+}$at neutral $\mathrm{pH}(\mathrm{pH}=7.12)$ despite the presence of only three phenol groups in its structure. This important result suggests therefore that water-cryptophane possessing a larger number of phenol groups grafted onto the benzene rings are able to bind $\mathrm{Tl}^{+}$in pure water with a great efficacy. A modification of the structure of these cryptophanes to improve their solubility in water or their incorporation into polymer matrix can be envisaged to prepare efficient materials for removing traces of thallium(I) in aqueous phase. Thus, cryptophane derivatives can find applications in environmental chemistry in solving problems related to water pollution by traces of thallium (I).

\section{EXPERIMENTAL DETAILS}

Mass spectra (HRMS) were performed by the Centre de Spectrométrie de Masse, University of Lyon. Analyses were performed with a hybrid quadrupole-time of flight mass spectrometer, microToF QII equipped with an Electrospray ion source. Data Analysis ${ }^{\circledR} 4.0$ was used for instrument control, data collection, and data treatment. HRMS analyses were performed in full scan MS with a mass range from 50 to $2000 \mathrm{Da}$ at an acquisition rate of $1 \mathrm{~Hz}$. Transfer parameters were: RF Funnel 1, 200 V; RF Funnel 2, $200 \mathrm{~V}$; hexapole, $50 \mathrm{~V}$; transfer time, $70 \mu$ s and PrePulse storage time, $1 \mu$ s Before each acquisition batch, external calibration of the instrument was performed with a sodium formate clusters solution. ${ }^{1} \mathrm{H}$ and ${ }^{13} \mathrm{C}$ NMR spectra were recorded at 300 and $75.5 \mathrm{MHz}$, respectively. Chemical shifts are referenced to $\mathrm{Me}_{4} \mathrm{Si}\left({ }^{1} \mathrm{H},{ }^{13} \mathrm{C}\right)$. Column chromatographic separations were carried out over 
Merck silica gel $60(0.040-0.063 \mathrm{~mm})$. Analytical thin layer chromatography (TLC) was performed on MERCK silica gel TLC plates F-254. The solvents were distilled prior to use: DMF and $\mathrm{CH}_{2} \mathrm{Cl}_{2}$ from $\mathrm{CaH}_{2}$, THF from $\mathrm{Na} /$ benzophenone and pyridine from $\mathrm{KOH}$.

CAUTION: thallium salts are highly toxic. Thallium salts such as TlOAc must be handled with great care.

NMR Experiments. ${ }^{133} \mathrm{Cs}$ NMR spectra $(65.587 \mathrm{MHz})$ were recorded on a $11.7 \mathrm{~T}$ Bruker Avance spectrometer using a $5 \mathrm{~mm}$ probehead. A solution of $\mathrm{CsNO}_{3}$ was used as a chemical shift reference $(0 \mathrm{ppm})$. An interscan delay of $1 \mathrm{~s}$ was applied. The ${ }^{205} \mathrm{Tl}$ NMR experiments were performed on a $11.7 \mathrm{~T}$ Bruker Avance spectrometer using an $8 \mathrm{~mm}$ microimaging (Micro-5) probehead basis equipped with a homebuilt ${ }^{205} \mathrm{Tl} /{ }^{1} \mathrm{H}$ insert. A solution of thallium nitrate was used as a chemical shift reference $(0 \mathrm{ppm})$, and comparison was made with a solution of thallium acetate. For the ${ }^{205} \mathrm{Tl}$ NMR spectrum of $\mathbf{3}$, an interscan delay of $1.2 \mathrm{~s}$ was applied. The FID was apodized by an exponential window of $200 \mathrm{~Hz}$ before Fourier transformation.

\section{EXPERIMENTAL PROCEDURE}

Synthesis of cryptophane 6: methylbromoacetate $(95 \mu \mathrm{L})$ was added to a mixture of cryptophane 4 (0.09 g, $0.083 \mathrm{mmol})$, cesium carbonate $(0.163 \mathrm{~g}, 0.5 \mathrm{mmol})$ in DMF (3 mL) under an argon atmosphere. The mixture was heated to $60^{\circ} \mathrm{C}$ (oil bath) for 16 hours. Then, the mixture was poured into a biphasic solution of $\mathrm{CH}_{2} \mathrm{Cl}_{2}(10 \mathrm{~mL})$ and water $(10 \mathrm{~mL})$. The product was extracted twice with $\mathrm{CH}_{2} \mathrm{Cl}_{2}$. Then, the combined organic layers were washed once with water and dried over $\mathrm{Na}_{2} \mathrm{SO}_{4}$. Filtration and evaporation of the solvent gave a solid residue, which was subjected to column chromatography on silica gel $\left(\mathrm{CH}_{2} \mathrm{Cl}_{2} /\right.$ acetone: 90/10). Compound 6 was isolated as a white glassy product. Filtration on a frit gives 
compound $6(0.097 \mathrm{~g}, 90 \%)$ as a white crystalline solid. ${ }^{1} \mathrm{H} \mathrm{NMR}\left(\mathrm{CDCl}_{3}, 300 \mathrm{MHz}\right): \delta 7.51$ $-7.28(\mathrm{~m}, 30 \mathrm{H}) 6.80(\mathrm{~s}, 3 \mathrm{H}), 6.78(\mathrm{~s}, 3 \mathrm{H}), 6.71(\mathrm{~s}, 6 \mathrm{H}), 4.97(\mathrm{~m}, 6 \mathrm{H}), 4.525(\mathrm{~d}, 6 \mathrm{H}, J=13.5$ Hz), 4.32 (s, 6H), 4.28 - $4.16(\mathrm{~m}, 12 \mathrm{H}) 3.62(\mathrm{~s}, 9 \mathrm{H}), 3.375$ (d, 3H, $J=13.5 \mathrm{~Hz}), 3.355$ (d, 3H, $J=13.5 \mathrm{~Hz}) .{ }^{13} \mathrm{C}\left\{{ }^{1} \mathrm{H}\right\} \mathrm{NMR}\left(\mathrm{CDCl}_{3}, 75.5 \mathrm{MHz}\right) \delta 169.3,149.0,148.0,147.8,147.3,137.5$, $134.2,134.0,133.7,132.5,128.5,127.9,127.6,121.8,120.9,119.5,117.5,71.8,68.4,69.3$, 67.5, 51.8, 36.1. HRMS (ESI-TOF) $\mathrm{m} / z\left[\mathrm{M}+\mathrm{H}^{+}\right]$calcd for $\mathrm{C}_{78} \mathrm{H}_{73} \mathrm{O}_{18}, 1297.4791$, found 1297.4799.

Synthesis of cryptophane 8: benzylbromoacetate $(0.4 \mathrm{~mL})$ was added under argon to a mixture of cesium carbonate $(0.36 \mathrm{~g}, 1.1 \mathrm{mmol})$, cryptophane 4 (0.3 g, $0.28 \mathrm{mmol})$ in DMF (6 $\mathrm{mL}$ ). The mixture heated overnight at $60^{\circ} \mathrm{C}$ (oil bath) under an argon atmosphere. Then, after cooling, the mixture was poured in a mixture of $\mathrm{CH}_{2} \mathrm{Cl}_{2}(20 \mathrm{~mL})$ and water $(20 \mathrm{ml})$. The aqueous layer was extracted twice with $\mathrm{CH}_{2} \mathrm{Cl}_{2}(2 \times 20 \mathrm{~mL})$. The combined organic layers were then washed with water to remove DMF. The organic layer was dried over sodium sulphate. Filtration and evaporation of the solvent gave compound $\mathbf{8}$ as an oily product. This product was first subjected to column chromatography on silica gel (eluent: $\mathrm{CH}_{2} \mathrm{Cl}_{2} / \mathrm{Acetone}$ : 95/5). The evaporation of the solvents gave compound $\mathbf{8}$ as a yellow oily product. A second column chromatography on silica gel $\left(\mathrm{CH}_{2} \mathrm{Cl}_{2}\right.$ then $\mathrm{CH}_{2} \mathrm{Cl}_{2}$ /Acetone: $99 / 1 ; 97 / 3$ and $\left.96 / 4\right)$ allows us to recover compound $\mathbf{8}(0.34 \mathrm{~g} ; 80 \%)$ as a clean product after evaporation of the solvents. Compound 8 was isolated as a white glassy product. ${ }^{1} \mathrm{H} \mathrm{NMR}\left(\mathrm{CDCl}_{3}, 300 \mathrm{MHz}\right): \delta$ $7.50-7.20(\mathrm{~m}, 30 \mathrm{H}), 6.71(\mathrm{~s}, 3 \mathrm{H}), 6.69(\mathrm{~s}, 3 \mathrm{H}), 6.62(\mathrm{~s}, 3 \mathrm{H}), 6.59(\mathrm{~s}, 3 \mathrm{H}), 5.05(\mathrm{~m}, 6 \mathrm{H}), 4.91$ $(\mathrm{m}, 6 \mathrm{H}), 4.48(\mathrm{~d}, 3 \mathrm{H}, J=13.5 \mathrm{~Hz}), 4.45(\mathrm{~d}, 3 \mathrm{H}, J=13.5 \mathrm{~Hz}), 4.34(\mathrm{~m}, 6 \mathrm{H}), 4.25-4.05(\mathrm{~m}$, 12H), $3.27(\mathrm{~d}, 3 \mathrm{H}, J=13.5 \mathrm{~Hz}), 3.245(\mathrm{~d}, 3 \mathrm{H}, J=13.5 \mathrm{~Hz}) .{ }^{13} \mathrm{C}\left\{{ }^{1} \mathrm{H}\right\} \mathrm{NMR}\left(\mathrm{CDCl}_{3}, 75.5\right.$ MHz) $\delta 168.8,149.0,147.9,147.7,147.3,137.4,135.3,134.2,134.0,133.6,132.5,128.7$, 
$128.5,127.9,127.6,122.0,120.7,119.7,117.5,71.8,69.4,69.2,67.7,66.7,36.0$. HRMS (ESI-TOF) $m / z\left[\mathrm{M}+\mathrm{H}^{+}\right]$calcd for $\mathrm{C}_{96} \mathrm{H}_{85} \mathrm{O}_{18}$ 1525.5747, found 1525.5730 .

Synthesis of cryptophane 9: Hydrogen gas was bubbled at room temperature into a solution of compound $6(0.09 \mathrm{~g}, 0.07 \mathrm{mmol})$ and $\mathrm{Pd} / \mathrm{C}(10 \%)$ in a mixture of $\mathrm{CH}_{2} \mathrm{Cl}_{2}(4 \mathrm{~mL})$ in methanol $(3 \mathrm{~mL})$. The reaction was stirred for 16 hours at room temperature under a hydrogen atmosphere. The black solid was then filtered on celite. The solid was washed several times with $\mathrm{CH}_{2} \mathrm{Cl}_{2}$ and few drops of DMF to ensure that extraction is complete. The organic layer was then evaporated under reduce pressure to give a residue, which was purified on silica gel $\left(\mathrm{CH}_{2} \mathrm{Cl}_{2}\right.$ /acetone: $\left.90 / 10\right)$. Evaporation of the solvents gives compound $9(0.055 \mathrm{~g}, 80 \%)$ as a white glassy product, which was collected on a frit and washed with diethyl ether. ${ }^{1} \mathrm{H}$ NMR $\left(\mathrm{CDCl}_{3}, 300 \mathrm{MHz}\right): \delta 8.36(\mathrm{~s}, 3 \mathrm{H}), 6.80(\mathrm{~s}, 3 \mathrm{H}), 6.75(\mathrm{~s}, 3 \mathrm{H}), 6.57$ (s, 3H), $6.53(\mathrm{~s}, 3 \mathrm{H}), 4.69$ $(\mathrm{m}, 6 \mathrm{H}), 4.49(\mathrm{~d}, 3 \mathrm{H}, J=13.5 \mathrm{~Hz}), 4.41(\mathrm{~d}, 3 \mathrm{H}, J=13.5 \mathrm{~Hz}), 4.30-4.00(\mathrm{~m}, 12 \mathrm{H}), 3.78(\mathrm{~s}$, 9H), $3.28(\mathrm{~d}, 3 \mathrm{H} J=13.5 \mathrm{~Hz}), 3.155(\mathrm{~d}, 3 \mathrm{H}, J=13.5 \mathrm{~Hz}) .{ }^{13} \mathrm{C}\left\{{ }^{1} \mathrm{H}\right\} \mathrm{NMR}\left(\mathrm{CDCl}_{3}, 75.5 \mathrm{MHz}\right)$ $\delta 169.9,146.9,146.1,145.7,144.2,133.6,133.0,132.6,130.0,119.4,118.9,117.8,116.0$, 68.2, 68, 65.8, 51.7, 35.0, 34.8. HRMS (ESI-TOF) $\mathrm{m} / \mathrm{z}\left[\mathrm{M}+\mathrm{H}^{+}\right]$calcd for $\mathrm{C}_{57} \mathrm{H}_{55} \mathrm{O}_{18}$ 1027.3383, found 1027.3387.

Synthesis of cryptophane 3: Hydrogen gas was bubbled at room temperature into a solution of compound $8(0.31 \mathrm{~g}, 0.2 \mathrm{mmol})$ and $\mathrm{Pd} / \mathrm{C}(10 \%)$ in a mixture of $\mathrm{CH}_{2} \mathrm{Cl}_{2}(8 \mathrm{~mL})$ in methanol $(6 \mathrm{~mL})$. The reaction was stirred overnight at room temperature. The black mixture was then filtered over celite. The desired product was then extracted with a $\mathrm{NaOH}(0.5 \mathrm{M})$ solution $(75 \mathrm{~mL})$. The aqueous phase was washed once with $\mathrm{CH}_{2} \mathrm{Cl}_{2}$ and then cooled into ice. Acidification with $\mathrm{HCl}$ gives rise to compound a white product. The solid was collected on frit washed with water and dried in air. The solid was then finally washed with diethyl ether to 
give compound 3 as a white glassy product in quantitative yield $(0.2 \mathrm{~g}, 97 \%) .{ }^{1} \mathrm{H}$ NMR (DMSO-d, $300 \mathrm{MHz}): \delta 6.79(\mathrm{~s}, 3 \mathrm{H}), 6.75(\mathrm{~s}, 3 \mathrm{H}), 6.59(\mathrm{~s}, 3 \mathrm{H}), 6.53(\mathrm{~s}, 3 \mathrm{H}), 4.64(\mathrm{~m}, 6 \mathrm{H})$, $4.77(\mathrm{~d}, 3 \mathrm{H}, J=13.5 \mathrm{~Hz}), 4.40(\mathrm{~d}, 3 \mathrm{H}, J=13.5 \mathrm{~Hz}), 4.30-4.05(\mathrm{~m}, 12 \mathrm{H}), 3.27(\mathrm{~d}, 3 \mathrm{H}, J=$ $13.5 \mathrm{~Hz}), 3.14(\mathrm{~d}, 3 \mathrm{H}, J=13.5 \mathrm{~Hz}) .{ }^{13} \mathrm{C}\left\{{ }^{1} \mathrm{H}\right\} \mathrm{NMR}$ (DMSO- $\left.d_{6}, 75.5 \mathrm{MHz}\right) \delta 171.4,147.0$, $146.1,145.7,144.0,133.6,133.0,132.5,130.0,119.5,118.9,117.8,116.3,68.3,68.1,66.0$, 35.0, 34.9. HRMS (ESI-TOF) $m / z\left[\mathrm{M}+\mathrm{Na}^{+}\right]$calcd for $\mathrm{C}_{54} \mathrm{H}_{48} \mathrm{NaO}_{18}$ 1007.2733, found 1007.2764.

Supporting Information. ${ }^{1} \mathrm{H}$ and ${ }^{13} \mathrm{C}$ spectra of compounds 6, 8, 9 and 3. ${ }^{133} \mathrm{Cs}$ NMR spectra of compound 3 recorded in $\mathrm{NaOH}(0.1 \mathrm{M})$ at various temperatures. ${ }^{205} \mathrm{Tl} \mathrm{NMR}$ spectrum of compound 3 recorded in $\mathrm{NaOH}(0.1 \mathrm{M})$ at room temperature. Isothermal Titration Calorimetry experiments of compound $\mathbf{3}$ recorded under various experimental conditions. Imploded structures of cryptophane $\mathbf{3}$.

\section{AUTHOR INFORMATION}

Corresponding author

*E-mail: thierry.brotin@ens-lyon.fr

ORCID

Thierry Brotin: 0000-0001-9746-4706

Patrick Berthault:_0000-0003-4008-2912

Notes

The authors declare no competing financial interest. 


\section{ACKNOWLEDGEMENTS}

The CNRS and the CEA are acknowledged for financial support. The authors thank Kévin Chighine for the building of the ${ }^{205} \mathrm{Tl}$ insert.

\section{REFERENCES}

(1) Shaw, D. M. The Geochemistry of thallium. Geochimica et Cosmochimica Acta, 1962, 2, $118-154$.

(2) Ahrens, L. H. The Abundance of Thallium in the Earth's Crust. Science, 1947, 106, 268.

(3) Taylor, S. R. Abundance of the Chemical Elements in the Continental Crust: A new Table. Geochimica et Cosmochimica Acta, 1964, 28, 1273 - 1285.

(4) Zitko, V. Toxicity and Pollution Potential of Thallium. The Science of the Total Environment. 1975, 4, 185-192.

(5) Léonard, A.; Gerber, G. B. Mutagenicity, Carcinogenicity, and Teranogenicity of Thallium Compounds. Mutation Res. 1997, 387, 47-53.

(6) Maluszynski, M.J. Thallium in the Environment. Ochrona Srodowiska I Zasobow Naturalnych. 2009, 40, 31-38.

(7) Zasukhina, G. D.; Vasilyeva, I. M.; Sdirkova, N. I.; Krasovsky, G. N.; Vasyukovich, L. Y.; Kenesariev, U. I.; Butenko, P. G. Mutagenic Effect of Thallium and Mercury Salts on Rodent Cells with Different Repair Activities. Mutation res. 1983, 124, 163-173.

(8) John Peter, A. L.; Viraraghavan, T.; Thallium: A Review of Public Health and Environmental Concerns. Environ. Int., 2005, 31, 493-501.

(9) Clarke, L.B.; Sloss, L.L. Trace Elements : Emissions from Coal Combustion and Gasification. London : IEA Coal research : 1992 (chapter 2). 
(10) Saha, A. Thallium Toxicity : A growing concern. Indian J. Occup. Environ. Med. 2005, 9, 53-56.

(11) Lopez Anton, M. A.; Spears, D. A.; Somoano, M. D.; Tarazona, M. R. M. Thallium in Coal: Analysis and Environmental implications. Fuel. 2013, 105, 13-18.

(12) Chen, YH.; Wang, CL.; Liu, J.; Wang, J.; Qi, JY.; Wu, YJ. Environmental Exposure and Flux of Thallium by Industrial Activities Utilizing Thallium-Bearing Pyrite. Sci. China Earth Sci. 2013, 56, 1502-1509.

(13) Karbowska, B. Presence of Thallium in the Environment : Sources of Contaminations, Distribution and Monitoring Methods. Environ. Monit. Assess. 2016, 188, 640.

(14) Lisella, F. S.; Long, K. R.; Scott, H. G. Toxicology of Rodenticides and their Relation to Human Health. Journal of environmental health. 1970, 33, 231-237.

(15) Gratz, N. G. A Critical Review of Currently Used Single-Dose Rodenticides. Bull. Wld Hlth Org. 1973, 48, 469-477.

(16) Vyas, N. B. Rodenticide Incidents of Exposure and Adverse Effects on Non-Raptor Birds. Science of the Total Environment, 2017, 609, 68-76.

(17) Liu, J.; Luo, X.; Sun, Y.; Tsang, D. C. W.; Qi, J.; Zhang, W.; Li, N.; Yin, M.; Wang, J.; Lippold, H.; Chen, Y.; Sheng, G. Thallium Pollution in China and Removal Technologies for Waters: A review. Environment International, 2019, 126, 771-790.

(18) Wang, J.; Zhou, Y.; Dong, X.; Yin, M.; Tsang, D. C. W.; Sun, J.; Liu, J.; Song, G.; Liu, Y. Temporal Sedimentary Record of Thallium Pollution in an Urban Lake : An Emerging Thallium Pollution Source from Copper Metallurgy. Chemosphere. 2020, 242, 125172.

(19) Lin, T.-S., Nriagu, J. Thallium Speciation in the Great lakes. Environ. Sci. Technol. 1999, 33, 3394-3397.

(20) Ghezzi, L.; D’Orazio, M.; Doveri, M.; Lelli, M.; Petrini, R.; Giannecchini, R. Groundwater and Potentially Toxic Elements in a Dismissed Mining Area: Thallium 
Contamination of Drinking Spring Water in the Apuan Alps (Tuscany, Italy). Journal of Geochemical Exploration. 2019, 197, 84-92.

(21) Cheam, V. Thallium Contamination of Water in Canada. Water Qual. Res. J. Canada. 2001, 36, 851-877.

(22) Gomez-Gonzalez, M. A.; Garcia-Guinea, J.; Laborda, F.; Garrido, F. Thallium Occurrence and Partitioning in Soils and Sediments Affected by Mining Activities in Madrid Province (Spain). Science of the Total Environment. 2015, 536, 268-278.

(23) Twidwell, L. G.; Williams-Beam, C. Potential Technologies for Removing Thallium from Mine and Process Wasterwater: An Annotation of the Literature. Eur. J. Miner. Process. Environ. Prot., 2002, 2, 1-10.

(24) Memon, S. Q.; Memon, N.; Solangi, A. R.; Memon, J.-R. Sawdust: A Green and Economical Sorbent for Thallium Removal. Chemical Engineering Journal 2008, 140, 235240.

(25) John Peter, A. L.; Viraraghavan, T. Removal of Thallium from Aqueous Solutions by Modified Aspergillus Niger Biomass. Bioresource Technology 2008, 99, 618-625.

(26) Li, H.; Li, X.; Xiao, T.; Chen, Y.; Long, J.; Zhang, G.; Zhang, P.; Li, C.; Zhuang, L.; Li, K. Efficient Removal of Thallium(I) from Wastewater Using Flower-Like Manganese Dioxide Coated magnetic Pyrite Cinder. Chemical Engineering Journal 2018, 353, 867-877.

(27) Li, H.; Li, X.; Chen, Y.; Long, J.; Zhang, G.; Xiao, T.; Zhang, P.; Li, C.; Zhuang, L.; Huang, W. Removal and Recovery of Thallium from Aqueous Solutions via a Magnetitemediated Reversible Adsorption-Desorption Process. Journal of Cleaner Production 2018, 199, 705-715.

(28) Li, H.; Li, X.; Long, J.; Li, K.; Chen, Y.; Jiang, J.; Chen, X.; Zhang, P. Oxidation and Removal of Thallium and Organics from Wastewater Using a Zero-Valent-Iron-Based Fenton-Like Technique. Journal of Cleaner Production 2019, 221, 89-97. 
(29) Fu, X.; Li, L.; Yang, G.; Xu, X.; He, L.; Zhao, Z. Removal of Trace Thallium from Industrial Wastewater by $\mathrm{Fe}^{0}$-Electrocoagulation. Water 2020, 12, 1-18.

(30) Zhao, Z.; Xiong, Y.; Cheng, X.; Hou, X.; Yang, Y.; Tian, Y.; You, J.; Xu. L. Adsorptive Removal of Trace Thallium(I) from Wastewater: A Review and New Perspectives. Journal of Hazardous Materials. 2020, 393, 122378.

(31) Talanova, G. G.; Roper, E. D.; Buie, N. M.; Gorbunova, M. G.; Bartsch, R. A.; Talanov, V. S. Novel Fluorogenic Calix[4]arene-bis(crown-6-Ether) for Selective Recognition of Thallium(I). Chem. Commun. 2005, 5673-5675.

(32) Katsu, T.; Ido, K.; Takaishi, K.; Yokosu, H. Thallium(I)-Selective Membrane Electrodes Based on Calix[6]arene or Calix[5]arene Derivatives. Sensors and Actuators B, 2002, 87, $331-335$

(33) Dong, H.; Zheng, H.; Lin, L.; Ye, B. Determination of Thallium and Cadmium on a Chemically Modified Electrode with Langmuir-Blodgett Film of $p$-Allylcalix[4]arene. Sensors and Actuators B, 2006, 115, 303-308.

(34) Cheraghi, S.; Ali Taher, M.; Fazelirad, H. Voltammetric Sensing of Thallium at a Carbon Paste Electrode Modified with a Crown Ether . Microchim. Acta, 2013, 180, 1157-1163.

(35) Chester, R.; Sohail, M.; Ogden, M. I.; Mocerino, M.; Pretsch, E.; De Marco, R. A Calixarene-Based Ion-Selective Electrode for Thallium(I) Detection. Analytica Chimica Acta, 2014, $851,78-86$. 
(36) Brotin, T.; Cavagnat, D.; Berthault, P.; Montserret, R.; Buffeteau, T. Water-Soluble Molecular Capsule for the Complexation of Cesium and Thallium Cations. J. Phys. Chem. B 2012, 116, 35, 10905-10914.

(37) Brotin, T.; Goncalves, S.; Berthault, P.; Cavagnat, D.; Buffeteau, T. Influence of the Cavity Size of Water-Soluble Cryptophanes on Their Binding Properties for Cesium and Thallium Cations. J. Phys. Chem B, 2013, 117, 41, 12593-12601.

(38) Chapellet, L. L.; Dognon, J.-P.; Jean, M.; Vanthuyne, N.; Berthault, P.; Buffeteau, T.; Brotin, T. Experimental and Theoretical Study of the Complexation of Cesium and Thallium Cations by a Water-Soluble Cryptophane. ChemistrySelect. 2017, 2, 5292-5300.

(39) Matthews, S. E.; Rees, N. H.; Felix, V.; Drew, M. G. B.; Beer, P. D. Thallium $\pi$-Cation Complexation by Calix[4]tubes : ${ }^{205} \mathrm{Tl}$ NMR and X-ray Evidence. Inorg. Chem. 2003, 42, 3, $729-734$

(40) Roper, E. D.; Talanov, V. S.; Butcher, R. J.; Talanova, G. G. Selective Recognition of Thallium(I) by 1,3-Alternate Calix[4]arene-bis(crown-6 Ether) : A New Talent of the Known Ionophore. Supramolecular Chemistry. 2008, 20, 217-219.

(41) Cuc, D.; Bouguet-Bonnet, S.; Morel-Desrosiers, N.; Morel, J.-P.; Mutzenhardt, P.; Canet, D. Behavior of Cesium and Thallium Cations inside a Calixarene Cavity As Probed by Nuclear Spin Relaxation. Evidence of Cation $-\pi$ Interactions in Water. J. Phys. Chem. B 2009, $113,31,10800-10807$.

(42) Makrlik, E.; Dybal, J.; Vanura, P. Interaction of the Thallium Cation with 1,3-alternate25,27-bis(1-octyloxy)calix[4]arene-crown-6 : Experimental and Theoritical Study. Journal of Molecular Structure, 2013, 1042, 73-77.

(43) Haddadi, H.; Alizadeh, N.; Shamsipur, M.; Asfari, Z.; Lippolis, V.; Bazzicalupi, C. Cation- $\pi$ interaction in Complex Formation Between $\mathrm{Tl}^{+}$Ion and calix[4]crown- 6 and Some 
calix[4]biscrown-6 Derivatives: Thallium-203 NMR, Proton NMR, and X-ray Evidence. Inorg. Chem. 2010, 49, 15, 6874-6882.

(44) Chester, R. T.; Couton, D.; Lobler, R.; Mocerino, M.; Ogden, M. I.; Pettersen, J. K.; Skelton, B. W.; White, A. H. The extraction of Thallium(I) and Silver(I) Ions with 1,3Alternate Calix[4]arene Derivatives. J. Incl. Phenom. Macrocycl. Chem. 2011, 71, 471-477.

(45) Brotin, T.; Dutasta, J.-P. Cryptophanes and their Complexes : Present and Future. Chem. Rev. 2009, 109, 1, 88-130.

(46) Brotin, T.; Jeanneau, E.; Berthault, P.; Léonce, E.; Pitrat, D.; Mulatier, J.-C. Synthesis of Cryptophane-B : Crystal Structure and Study of its Complex with Xenon. J. Org. Chem. 2018, $83,23,14465-14471$.

(47) Léonce, E.; Dognon, J.-P.; Pitrat, D.; Mulatier, J.-C.; Brotin, T.; Berthault, P. Accurate pH Sensing Using Hyperpolarized ${ }^{129}$ Xe NMR Spectroscopy. Chem. Eur. J. 2018, 24, 65346537.

(48) Huber, G.; Brotin, T.; Dubois, L.; Desvaux, H.; Dutasta, J.-P.; Berthault, P. Water soluble cryptophanes showing unprecedented affinity for xenon: candidates as NMR-based biosensors. J. Am. Chem. Soc. 2006, 128, 6239-6246.

(49) Baydoun, O.; De Rycke, N.; Léonce, E.; Boutin, C.; Berthault, P.; Jeanneau, E.; Brotin, T. Synthesis of Cryptophane-223-Type Derivatives with Dual Functionalization. J. Org. Chem. 2019, 84, 14, 9127-9137.

(50) Brotin, T.; Montserret, R.; Bouchet, A.; Cavagnat, D.; Linares, M.; Buffeteau, T. High Affinity of Water-Soluble Cryptophanes for Cesium Cation. J. Org. Chem. 2012, 77, 2, 1198 1201.

(51) Chapellet, L.L.; Cochrane, J. R.; Mari, E.; Boutin, C.; Berthault, P.; Brotin, T. Synthesis of Cryptophanes with Two Different Reaction Sites: Chemical Platforms for Xenon Biosensing J. Org. Chem. 2015, 80, 6143 - 6151. 